\title{
A dynamic model of feed intake regulation in dairy cows. Model description
}

\author{
H. Petruzzi ${ }^{1,2}$ and A. Danfær ${ }^{1}$ \\ ${ }^{1}$ Research Centre Foulum, Danish Institute of Agricultural Sciences, \\ Department of Animal Nutrition and Physiology \\ PO Box 50, DK-8830 Tjele, Denmark \\ ${ }^{2}$ EEA Anguil "Ing Agr. Guillermo Covas”, Instituto Nacional de Tecnología Agropecuaria \\ P.O. Box 11, 6326 Anguil, La Pampa, Argentina
}

(Received 25 November 2002; revised version 25 November 2003; accepted 14 January 2004)

\begin{abstract}
A dynamic, mechanistic and deterministic model of feed intake regulation in dairy cows is described. The model is based on a conceptual model of feed intake regulation involving an interplay between rumen function and energy transactions. Two interconnected submodels are included, the rumen submodel (RS), adapted from a previously developed rumen model and the feed intake regulation submodel (FIRS). From RS rumen digesta load in terms of $\mathrm{kg}$ of NDF is calculated. FIRS not only describes the feed intake regulation but also the digestion, absorption and flow of nutrients beyond the rumen. Energy transactions in the model are related to the simulated difference between the capacity to use energy and the intake of metabolized energy. In the model, energy outputs of the animal include not only the energy needed for maintenance and milk production but also the energy needed to support a genetically determined time course of body reserves. Body reserves, both the absolute level and the rate of mobilization are considered in the regulation of feed intake. A preliminary evaluation of the model behaviour for a typical diet and animal inputs showed predicted values within expected values for feed intake, body condition score and body weight.
\end{abstract}

KEY WORDS: model, evaluation, intake regulation, body reserves, dairy cows

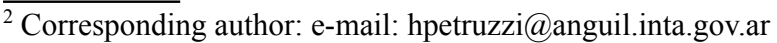




\section{INTRODUCTION}

Prediction of feed intake in ruminants is of major economic importance. This has led to the formulation of many mechanistic intake prediction models in ruminants, either standing alone or as part of whole animal models or as a component of ruminant livestock production systems models, during the last two decades. However, a recent analysis of some of the published models revealed serious drawbacks not only in the concepts and hypotheses on which they are based, but also in their mathematical implementation (Pittroff and Kothmann, 2001). Another conclusion from this paper is that almost all feed intake prediction models for cattle are based on the bi-phasic hypothesis of intake regulation (physical by fill in reticulorumen or physiological by energy demand) which has been rejected as a valid hypothesis through literature reviews (Weston, 1996; Pittroff and Kothmann, 1999) or from experimental work (Rinne et al., 2002).

The size of body reserves and its variation through the lactation cycle is broadly recognised by both its economic significance in terms of feed management and by the health status and reproductive performance of the animal. Body reserves and/ or its variation has only been exceptionally included into a few mechanistic feed intake prediction models (Sanders and Cartwright, 1979; Williams et al., 1989; Mertens, 1994) and when included it was done in a highly divergent manner (Pittroff and Kothmann, 2001).

The objective of this work was to develop a dynamic, mechanistic and deterministic model that will describe the regulation of feed intake in lactating dairy cows in which the physical and metabolic signals that regulate the initiation or cessation of feed intake are integrated.

\section{MODEL DESCRIPTION}

The proposed feed intake regulation model (FIRM) includes to interconnected submodels, the rumen submodel (RS) and the feed intake regulation submodel (FIRS). A version of the rumen submodel with a constant value of intake has been published previously (Petruzzi et al., 2002). It describes the digestion and flow of nutrients from the rumen and gives information to the FIRS about the status of nutrient pools in the rumen as well as the flow of different nutrients out of the rumen. The version of RS connected to FIRS is adapted to work on discontinuous feed intake.

The FIRS describes not only the mechanism of intake regulation in the dairy cow but also describes the digestion, absorption and flow of nutrients beyond the rumen and updates information about the dairy cow like body weight and body condition score among other variables. 
The mechanism of feed intake regulation in the FIRS is based on the conceptual model of feed intake regulation proposed by Weston $(1985,1996)$ and basically involves an interplay between rumen function and energy transactions. This conceptual model assumes that the capacity of the ruminant to dispose of energy is the driving component of the system constituted by the sum of the energy needed for maintenance, growth, reproduction and milk production. This capacity is reduced when constraints from the diet or from the environment are imposed to the animal. Certain constraints imposed by the forage prevent the animal to meet the capacity of energy use generating an energy deficit in the animal, which in turns generates hunger signals directly related to the magnitude of the deficit. A direct relationship is assumed between the clearance rate from the rumen and the amount of rumen digesta. This digesta load generates satiety signals, which are also in direct relation to the magnitude of the load once a threshold value is reached. When these signals more than balance the hunger signals derived from the energy deficit the feeding drive is overruled.

No experiments were carried out to develop this model and therefore, parameter values are derived entirely from existing data, published as well as unpublished. Abbreviations, description and units of the variables and the constants used in the FIRS are given in Tables 1 and 2, respectively. The Appendix describes all the equations used in the FIRS model. Along the paper, bold numbers between brackets refer to the equation number in the Appendix and italic type letters between brackets refer to the variable or constant abbreviations. The model is developed using the graphical modelling software Powersim ${ }^{\circledR}$, version 2.5 (1996). Runge-Kutta $4^{\text {th }}$ order integration method is used for the numerical solution of the differential equations with a time step of $0.2 \mathrm{~h}$. Energy transactions are given in MJ units. All flow rates are expressed in units of mol carbon (C), mol nitrogen $(\mathrm{N}), \mathrm{MJ}$ or $\mathrm{kg}$ per hour or day. The simulation period is given as an input.

\section{The energy deficit in the animal}

Energy deficit is the term proposed originally by Weston $(1985,1996)$ to relate the energy transactions with digesta load in his conceptual model. It is estimated as the capacity to use energy minus energy intake.

In the FIRM, energy difference ( $E_{-}$diff) is the term used to relate the energy transactions with digesta load and equation (1) represents the calculation of this term. Energy difference is computed as the difference between an energy balance calculated by the model (E_balance) and an optimum energy balance determined from a standard curve of corporal condition (E_bal_optimum) plus a factor adjusting this difference according to the initial and actual value of body condition of the dairy cow (Fac_BCS). 
TABLE 1

Abbreviations, description and units of the variables used in the feed intake regulation model

\begin{tabular}{|c|c|c|}
\hline Code & Description & Unit \\
\hline $\mathrm{Ab} \_\mathrm{AC} \_\mathrm{HG}$ & Absorption of acetate from the hindgut & $\mathrm{mol} \mathrm{C} \mathrm{h}^{-1}$ \\
\hline $\mathrm{Ab} \_\mathrm{B} U_{-}^{-} \mathrm{HG}$ & Absorption of butyrate from the hindgut & $\mathrm{mol} \mathrm{C} \mathrm{h}^{-1}$ \\
\hline Ab_PR_HG & Absorption of propionate from the hindgut & $\mathrm{mol} \mathrm{C} \mathrm{h}^{-1}$ \\
\hline Adjust_Act & Effect of actual BCS of the animal on feed intake & $\mathrm{MJ} \mathrm{h}^{-1}$ \\
\hline Adjust_Ini & $\begin{array}{l}\text { Effect of BCS of the animal at beginning of the lactation } \\
\text { on feed intake }\end{array}$ & $\mathrm{MJ} \mathrm{h}^{-1}$ \\
\hline Amino_acids & Absorption of amino acids in small intestine & $\mathrm{mol} \mathrm{N} \mathrm{h}^{-1}$ \\
\hline BCS_optimum & Optimum BCS of the dairy cow in BCS units & \\
\hline BCSC_M & Body Condition Score Change calculated by the model & \\
\hline BCSC_optimum & Optimum BCS change & \\
\hline CH4_HG & Production of methane in the hindgut & $\mathrm{mol} \mathrm{C} \mathrm{h}^{-1}$ \\
\hline $\mathrm{CO} 2 \_\mathrm{HG}$ & Production of carbon dioxide in the hindgut & $\mathrm{mol} \mathrm{C} \mathrm{h}^{-1}$ \\
\hline D_X & $\begin{array}{l}\text { Delayed information of the variable } \mathrm{X} \text {. The value is } \\
\text { delayed by } 24 \mathrm{~h} \text { unless otherwise stated }\end{array}$ & $\begin{array}{l}\text { Units of } \\
\text { variable X }\end{array}$ \\
\hline Daily_Preg_E_Ret & Daily Net Energy retained in foetus & $\mathrm{MJ} \mathrm{d}^{-1}$ \\
\hline DE & Digestible energy & $\mathrm{MJ} \mathrm{h}^{-1}$ \\
\hline Der_Load & The derivative of the variable Rumen_load & $\mathrm{kg} \mathrm{h}^{-1}$ \\
\hline DMI & Rate of dry matter intake & $\mathrm{kg} \mathrm{DM} \mathrm{h}^{-1}$ \\
\hline E_bal_optimum & $\begin{array}{l}\text { Energy balance optimum according to an optimum BCS } \\
\text { curve }\end{array}$ & $\mathrm{MJ} \mathrm{h}^{-1}$ \\
\hline E_balance & Energy balance (net energy for body gain) & $\mathrm{MJ} \mathrm{h}^{-1}$ \\
\hline E_BCS_h & Energy contained per unit of BCS change & $\mathrm{MJ} \mathrm{BCS}^{-1}$ \\
\hline E_diff_h & Energy difference (Capacity to use E - Useful E intake) & $\mathrm{MJ} \mathrm{h}^{-1}$ \\
\hline Endog_protein & Secretion of endogenous faecal protein & $\mathrm{mol} \mathrm{N} \mathrm{h}^{-1}$ \\
\hline EV_Milk & Energy value of milk & $\mathrm{MJ} \mathrm{kg}^{-1}$ \\
\hline Fac_BCS & Influence of BCS on feed intake & $\mathrm{MJ} \mathrm{h}^{-1}$ \\
\hline Faecal_C & Faecal C excretion & $\mathrm{mol} \mathrm{C} \mathrm{h}^{-1}$ \\
\hline Faecal_E & Excretion of faecal energy & $\mathrm{MJ} \mathrm{h}^{-1}$ \\
\hline Faecal_N & Faecal N excretion & $\mathrm{mol} \mathrm{N} \mathrm{h}^{-1}$ \\
\hline Fatty_acids & Absorption of fatty acids in the small intestine & $\mathrm{mol} \mathrm{C} \mathrm{h}^{-1}$ \\
\hline Feed_intake & Rate of dry matter intake & $\mathrm{kg} \mathrm{d}^{-1}$ \\
\hline Fermentable_HG & Fermentable substrates in the hindgut & $\mathrm{mol} \mathrm{C} \mathrm{h}^{-1}$ \\
\hline GE_intake & Gross energy intake & $\mathrm{MJ} \mathrm{h}^{-1}$ \\
\hline Glucose & Absorption of glucose in the small intestine & $\mathrm{mol} \mathrm{C} \mathrm{h}^{-1}$ \\
\hline $\mathrm{HE}$ & Total heat production & $\mathrm{MJ} \mathrm{h}^{-1}$ \\
\hline HE_Preg & Heat Energy due to pregnancy & $\mathrm{MJ} \mathrm{d}^{-1}$ \\
\hline Lactation_time & $\begin{array}{l}\text { Lactation time (days after calving) during the simulation } \\
\text { period }\end{array}$ & $\mathrm{D}$ \\
\hline Lipid_HG & Entrance of fatty acids into the hindgut & $\mathrm{mol} \mathrm{C} \mathrm{h}^{-1}$ \\
\hline Lipid_SI & Entrance of fatty acids into the small intestine & $\mathrm{mol} \mathrm{C} \mathrm{h}^{-1}$ \\
\hline Load_Reg & $\begin{array}{l}\text { This variable takes the value zero when rumen load } \\
\text { allows for eating. Otherwise, the value is } 1\end{array}$ & \\
\hline
\end{tabular}


TABLE 1

continued

\begin{tabular}{|c|c|c|}
\hline Code & Description & Unit \\
\hline Load_RegA & $\begin{array}{l}\text { This variable takes the value zero when the variable } \\
\text { Load is decreasing and is below a Lower limit. } \\
\text { Otherwise, the value is } 1\end{array}$ & \\
\hline Load_RegB & $\begin{array}{l}\text { This variable takes the value zero when the variable } \\
\text { load is constant or increasing and is below an upper } \\
\text { limit }\end{array}$ & \\
\hline Lower & Lower limit for rumen digesta load & $\mathrm{kg}$ \\
\hline M_Daily_Preg_E_Ret & Metabolizable daily energy retained in foetus & $\mathrm{MJ} \mathrm{d}^{-1}$ \\
\hline$\overline{\mathrm{ME}}$ & Metabolizable energy & $\mathrm{MJ} \mathrm{h}^{-1}$ \\
\hline Methane_E & Total production of methane energy & $\mathrm{MJ} \mathrm{h}^{-1}$ \\
\hline Milk_E & Total energy in milk & $\mathrm{MJ} \mathrm{d}^{-1}$ \\
\hline MY & Daily milk yield & $\mathrm{kg} \mathrm{d}^{-1}$ \\
\hline MY_Preg_Red & $\begin{array}{l}\text { Daily milk yield reduction due to pregnancy. Effects } \\
\text { of pregnancy on MY starts in week } 18 \text { of pregnancy } \\
\text { (126 days) }\end{array}$ & $\mathrm{kg} \mathrm{d}^{-1}$ \\
\hline NDF_SI & Entrance of NDF into the small intestine & $\mathrm{mol} \mathrm{C} \mathrm{h}^{-1}$ \\
\hline OtherCHO_SI & $\begin{array}{l}\text { Entrance of other carbohydrates fraction into the small } \\
\text { intestine }\end{array}$ & $\mathrm{mol} \mathrm{C} \mathrm{h}^{-1}$ \\
\hline Protein_HG & Entrance of protein into the hindgut & $\mathrm{mol} \mathrm{N} \mathrm{h}^{-1}$ \\
\hline Protein_SI & Entrance of protein into the small intestine & $\mathrm{mol} \mathrm{N} \mathrm{h}^{-1}$ \\
\hline PW & Weeks since conception & week \\
\hline RBF_Optimum & Optimal backfat during the lactation period & $\mathrm{mm}$ \\
\hline Rumen_load & Mass of total NDF in the rumen. & $\mathrm{kg}$ \\
\hline Starch_SI & Entrance of starch into the small intestine & $\mathrm{mol} \mathrm{C} \mathrm{h}^{-1}$ \\
\hline Sugar_SI & Entrance of sugar into the small intestine & $\mathrm{mol} \mathrm{C} \mathrm{h}^{-1}$ \\
\hline Sugar_starch_HG & Entrance of sugar and starch into the hindgut & $\mathrm{mol} \mathrm{C} \mathrm{h}^{-1}$ \\
\hline Total_Preg_E_Ret & $\begin{array}{l}\text { Total Net Energy retained at time } t \text { in the gravid foetus } \\
\text { in cattle }\end{array}$ & MJ \\
\hline TPR & Total NDF Particles in the rumen & mol C \\
\hline Upd_BCS & Actual BCS of the dairy cow. Value updated daily & \\
\hline Upd_BW & Updated body weight & $\mathrm{kg}$ \\
\hline Upper & Upper limit for rumen digesta load & $\mathrm{kg}$ \\
\hline Urinary_E & Excretion of urinary energy & $\mathrm{MJ} \mathrm{h}^{-1}$ \\
\hline
\end{tabular}

\section{Determination of energy balance}

For the estimation of the energy balance (E_balance) (2) in the model, metabolizable energy $(M E)(3)$ is determined first and then from this, the energy produced as heat, and the energy needed for pregnancy and milk production are deduced to obtain the energy balance. Total energy input in the model (GE_Intake) (4) is estimated as the product of the rate of dry matter intake $(D M I)$ of the ration and the content of gross energy of the diet $(G E)$. This last value is depending on diet 
TABLE 2

Abbreviations, description and value and units of the constants used in the feed intake regulation model

\begin{tabular}{|c|c|c|c|}
\hline Abbreviation & Description & Value & Units \\
\hline a_1 & $\begin{array}{l}\text { Scaling coefficient to express different milk } \\
\text { yield potentials. Values for first, second and } \\
\text { third or more parities }\end{array}$ & $\begin{array}{l}32.1 \\
44.9 \\
52.8\end{array}$ & \\
\hline Alfa1 & Constant in the calculation of Upper & 4.15 & \\
\hline Alfa2 & Constant in the calculation of Upper & 4 & \\
\hline Alfa3 & Constant in the calculation of Upper & 0.925 & \\
\hline Alfa4 & Constant in the calculation of Upper & 1.3 & \\
\hline Alfa5 & Constant in the calculation of Upper & 1.9 & \\
\hline aMR & $\begin{array}{l}\text { Factor } a \text { in Coulon (1995) equation for } \\
\text { reduction in MY due to pregnancy. Values } \\
\text { for primiparous and multiparous low or high- } \\
\text { producing dairy cows, respectively }\end{array}$ & $\begin{array}{l}4.248 \\
2.571 \\
3.839\end{array}$ & \\
\hline b_1 & $\begin{array}{l}\text { Rate at which milk yield increase to a peak. } \\
\text { Values for first, second and third or more } \\
\text { parities }\end{array}$ & $\begin{array}{l}0.0694 \\
0.0916 \\
0.0888\end{array}$ & \\
\hline bMR & $\begin{array}{l}\text { Factor } b \text { in Coulon } 1995 \text { equation for } \\
\text { reduction in MY due to pregnancy. Values } \\
\text { for primiparous and multiparous low or high- } \\
\text { producing dairy cows, respectively }\end{array}$ & $\begin{array}{l}-0.08 \\
-0.035 \\
-0.094\end{array}$ & \\
\hline Body_weight & Initial body weight of the dairy cow & Input & $\mathrm{kg}$ \\
\hline Butterfat_Milk & Butterfat content in milk & Input & $\mathrm{g} \mathrm{kg}^{-1}$ milk \\
\hline c_1 & $\begin{array}{l}\text { Rate of decline of Milk Yield } \\
\text { Values for first, second and third or more } \\
\text { parities, respectively }\end{array}$ & $\begin{array}{l}0.00218 \\
0.00322 \\
0.00393\end{array}$ & \\
\hline Calf_Birth_W & Calf birth weight for Holstein breed & 45 & $\mathrm{~kg}$ \\
\hline Conception_Day & $\begin{array}{l}\text { Stage of lactation at the time of conception } \\
\text { (Days) }\end{array}$ & 92 & $\mathrm{~d}$ \\
\hline Cte_137 & Constant in the calculation of Adjust_Ini & 0.0025 & \\
\hline Cte $\overline{1}$ & Constant in the calculation of Sigm 1 & 0.000002 & \\
\hline Cte3 & Constant in the calculation of Sigm 1 & 2.84 & \\
\hline Day1 & Length of the day in the model & 24 & $\mathrm{~h}$ \\
\hline Diff & $\begin{array}{l}\text { Difference between Upper and Lower limit for } \\
\text { rumen digesta load }\end{array}$ & 0.6 & $\mathrm{~kg}$ \\
\hline Eating & Rate of dry matter intake during eating & 3.3 & $\mathrm{~kg} \mathrm{~h}^{-1}$ \\
\hline GE & Gross energy in feed dry matter & Input & $\mathrm{MJ} \mathrm{kg}^{-1}$ \\
\hline Go & $\begin{array}{l}\text { Degree of maturity of milk production system } \\
\text { at calving. Values for first, second and third or } \\
\text { more parities, respectively }\end{array}$ & $\begin{array}{l}0.206 \\
0.245 \\
0.089\end{array}$ & \\
\hline Ini_Lact_time & Lactation time at the beginning of the simulation & Input & $\mathrm{D}$ \\
\hline Initial_BCS & $\begin{array}{l}\text { Initial BCS of the dairy cow at the beginning } \\
\text { of the simulation period }\end{array}$ & Input & \\
\hline K_BCS & Factor used in calculation of Adjust_Actual & 100 & \\
\hline
\end{tabular}


TABLE 2

continued

\begin{tabular}{|c|c|c|c|}
\hline Abbreviation & Description & Value & Units \\
\hline K_EP & Fractional rate constant of endogenous protein & 0.2856 & Mol N kg DM-1 \\
\hline K_HE & Factor used in calculation of $H E$ & 0.08 & \\
\hline K_UE & $\begin{array}{l}\text { Fractional rate constant of gross energy lost } \\
\text { as urine }\end{array}$ & 0.04 & \\
\hline Lact1 & Constant in the calculation of RBF_Optimum & 22.069 & \\
\hline Lact2 & Constant in the calculation of RBF_Optimum & 0.236 & \\
\hline Lact3 & Constant in the calculation of RBF_Optimum & 0.00201 & \\
\hline Lact4 & Constant in the calculation of RBF_Optimum & $610^{-6}$ & \\
\hline Lact5 & Constant in the calculation of RBF_Optimum & $6.3210^{-9}$ & \\
\hline Lactose_Milk & Lactose content in milk & Input & $\mathrm{g} \mathrm{kg}^{-1}$ milk \\
\hline Parity & Parity number of the cow $(1,2$ or 3$)$ & Input & \\
\hline Peak_MY & Peak Milk Yield (default $=0$ ) & Input & $\mathrm{kg} \mathrm{d}^{-1}$ \\
\hline Pot_MY & $\begin{array}{l}\text { Potential annual milk yield (305 DIM) } \\
(\text { default }=0)\end{array}$ & Input & $\operatorname{kg~}^{-1}$ \\
\hline Protein_Milk & Crude protein content in milk & Input & $\mathrm{g} \mathrm{kg}^{-1}$ milk \\
\hline
\end{tabular}

composition and is given as input to the model at the beginning of the simulation. From the estimated gross energy intake, the energy losses in faeces (Faecal_E), urine (Urinary_E) and methane (Methane_E) are subtracted to calculate $M E$.

Faecal_E (5) is the sum of the energy contained in faeces in carbon and nitrogen compounds. These energy values are estimated as the product of the respective flows of $\mathrm{C}$ and $\mathrm{N}$ compounds (Faecal_C and Faecal_N) and the corresponding heat of combustion $\left(0.546 \mathrm{MJ} \mathrm{mol}^{-1} \mathrm{C}^{-}\right.$and $23.7 \mathrm{MJ} \mathrm{kg}^{-1}$ protein, respectively). Faecal_C (6) is obtained by summing all carbon fractions entering the hindgut minus the absorption and disappearance of short chain fatty acids (SCFA) and fermentation gases produced in the hindgut. No digestion of NDF is assumed in the small intestine (SI), therefore the amount of NDF entering the hindgut (NDF_SI) (7) is the same amount of NDF leaving the rumen. For determination of NDF as well as all other nutrients and microbial fractions passing to the duodenum, see Petruzzi et al. (2002).

The fraction of other carbohydrates (cell wall carbohydrates other than NDF, i.e. pectins etc.) entering the SI (OtherCHO_SI) (8) corresponds to the sum of the two outflows from rumen of the other carbohydrates fractions and the corresponding proportion of other $\mathrm{C}$ fraction (0.0937) from the microbial $\mathrm{C}$ passage out of rumen. As for NDF, no digestion of the other carbohydrates fraction is assumed in SI.

The starch and sugar fractions entering SI (Sugar_SI and Starch_SI) (10 and 11, respectively) from the reticulorumen are partly digested and absorbed as glucose 
(Glucose) (12), and the rest enters the hindgut (Sugar_Starch_HG) (9). The rate constant of digestion of sugar and starch in SI (0.884) as well as the rest of the rate constants of digestion and absorption of the different nutrient fractions in SI and hindgut were obtained from the model Karoline (Danfaer, 1998). Both models, the actual version of Karoline and FIRM were run with the same diet and the mentioned postruminal rates of absorption and digestion of nutrients in FIRM were adjusted to match results from the Karoline model.

Lipids entering the SI (Lipid_SI) (14) are constituted by fatty acids from dietary origin not digested in rumen and by the proportion of fatty acids in microbes (0.1817) flowing out of the rumen. Most of these fatty acids $(83.3 \%)$ are absorbed from the SI in the model (15). The remaining fraction (Lipid_HG) (13) is the fatty acids entering the hindgut.

The protein flow into the hindgut (Protein_HG) is calculated as the protein entering the SI (Protein_SI) plus the undigested endogenous protein (Endog_protein) minus the fraction of protein digested in SI and absorbed as amino acids (Amino_acids) (16). The protein entering the duodenum (Protein_SI) is the sum of microbial protein and undegraded dietary protein (17). Endog_protein in the model is a function of feed intake (18). The digestion rate constant of protein in the small intestine is taken as $0.735(\mathbf{1 9})$.

All C fractions (except Lipid_HG) entering the hindgut and the C contained in dietary and microbial protein flowing into the hindgut constitute the fermentable $\mathrm{C}$ fraction (Fermentable_HG) (20) and from this the different SCFA and fermentation gases are produced (21 to $\mathbf{2 5}$ ). Rate constants for the production and absorption of acetate, propionate, butyrate, methane and carbon dioxide are 0.0813 , $0.0355,0.0242,0.0158$ and 0.0382 , respectively, estimated from the model Karoline (Danfaer, 1998).

Faecal_N(26) is N contained in protein entering the hindgut plus the net difference between urea uptake and ammonia absorption in the hindgut $(0.184 \mathrm{~mol}$ $\mathrm{N} \mathrm{h}^{-1}$ ), estimated from the Karoline model.

Total energy lost as methane by the animal (Methane_E) is obtained by adding the methane produced in the rumen and that produced in hindgut (27). A reduction factor for methane formation (0.75) was taken from Danfaer (1998). Heat of combustion value per mol of methane is $0.890 \mathrm{MJ}$.

It is assumed in the model that a constant fraction of the gross energy intake is lost as urine energy (Urinary_E) (28), and the fractional rate constant for this equation is 0.04 . The assumption that urinary energy losses are related to GE intake has been used previously in modelling purposes (Danfaer, 1998; Mills et al., 2001).

Energy lost as heat $(H E)$ is the total heat production and is calculated as a function of gross energy intake (GE_intake) and milk yield $(M Y)$ plus heat produced due to pregnancy $\left(H E \_\right.$preg) (29). The equation for heat pregnancy in non-preg- 
nant cows is estimated from literature data (Coppock et al., 1964; Holter et al., 1990; Gordon et al., 1995; Romo et al., 1996; Wilkerson et al., 1997; Sutton et al., 1998). HE_Preg is according to AFRC (1993) (30). The efficiency for growth of the concepta is 0.133 (AFRC, 1993).

Daily milk yield (MY) (31) can be given as an input to the model or calculated by an equation incorporated in FIRS. This equation is taken from Friggens et al. (1999) and reported originally by Emmans and Fisher (1986). In order to calculate the daily milk yield with this equation, information about the potential milk yield of the animal or the peak milk yield must be given to the model in addition to information about the parity number of the animal. With this equation it is possible to calculate potential milk yield for cows in their first, second and third or more parity. A total of four parameters, three coefficients and one scalar are used to calculate the equation. The $b_{-} l$ coefficient describes the rate at which milk yield increases to peak, Go quantifies the degree of maturity of the milk producing system at calving, and $c_{-} l$ describes the rate of decline in milk yield. $a_{-} l$ is the milk yield scalar. Although the statistical analysis carried out by Friggens et al. (1999) shows relatively small effect of parity on the coefficients $b_{-} l$ and Go, meaning that an average value could be used to predict potential milk yield across parities for the cited coefficients, all values for each coefficient and scalar in the equation are included in the FIRS.

The variable Lactation time represents time in days from parturition and is used not only in the previous equation, but also for the estimation of many other variables in the model. This variable is calculated from the initial time of simulation in the model (Ini_Lact_time) that is given as input, by default this variable takes the value 1, meaning that the simulation starts at the first day in lactation. This initial time of lactation is updated in the model every $24 \mathrm{~h}$ of simulation time with the constant Dayl (32).

Pregnancy has been proved to have a weak, but significant effect on milk yield in dairy cows (Coulon et al., 1995; Perochon et al., 1996). However, this effect is rarely taken into account in milk yield prediction models. The time at which pregnancy starts to have an effect on milk yield varies according to different authors and the importance given to that effect. Regardless of the milk yield potential of the cow or the time of conception, Coulon et al. (1995) have shown that the reducing effect of pregnancy can be detected from the $20^{\text {th }}$ week of pregnancy. The equation for the lactation curve provided by Friggens et al. (1999) does not take explicitly into account the reducing effect of pregnancy on milk yield, because only milk records taken until 240 days post calving were considered for its construction. The effect of pregnancy was modelled in FIRS by the equation provided by Coulon et al. (1995) (33), which is added to the original equation of Friggens et al. (1999). Milk yield reduction due to the effect of pregnancy starts in the model at day 126 of pregnancy with the effect differing for primiparous 
and multiparous cows, and within this last group, for low-or-medium producing $\left(<32.5 \mathrm{~kg}\right.$ milk d$\left.^{-1}\right)$ and high producing cows $\left(>32.5 \mathrm{~kg}\right.$ milk d$\left.^{-1}\right)$. Pregnancy week $(P W)(34)$ is computed in FIRS from the Lactation_time variable and the stage of lactation (in days) at the time of conception (Conception_day), a constant given as input to the model and set by default to day 92 .

Daily energy retained in foetus (Daily_Preg_E_Ret) (35 and 36) is calculated according to the equation provided by AFRC (1993) based on information about time of pregnancy $(P W)$ and calf birth weight (Calf_Birth_W). In the model, this last value is a constant that can be given as an input or a default value can be used (45 kg, a value for Holstein cattle given in AFRC, 1993).

Energy in milk is calculated as the product of $M Y$ and the energy value of milk (EV_Milk) (37). EV_Milk can be calculated by one of the three equations included in the model ( 38 to 40 ) depending on the information about milk composition available. The equations were taken from AFRC (1993). If no information about milk composition is available the model uses a constant value of $3.14 \mathrm{MJ} \mathrm{kg}^{-1}$ of milk (41).

\section{Determination of energy balance optimum and BCS factor}

There are two aspects regarding body reserves that are related to the performance of the dairy cow. The first is the state or the level of body reserves in the cow and the second is the rate of change of body reserves during lactation (Maltz et al., 2001).

Friggens (2001) has stated the importance of the conceptual distinction between the level and the rate of mobilization of body reserves when analysing reproductive performance. He also stated that these two modifiers of parameters of reproductive performance should be combined additively. The same principle, but applied to nutritional aspects is applied in this model.

\section{Determination of energy balance optimum}

The level of body reserves or corporal condition of dairy cows changes during the lactation period at a similar pattern across many experiments (Garnsworthy and Jones, 1987; Pedron et al., 1993; Waltner et al., 1993; Ruegg and Milton, 1995; Gallo et al., 1996; Domecq et al., 1997; Friggens et al., 1998; Schroeder, 2000; Mao et al., 2001; Pryce et al., 2001). Body reserves are mobilized during the first part of lactation, then recovered through middle lactation and stabilized at nearly a steady state in late lactation. However, differences in the amount of reserves being mobilized have been observed due to breed (Schroeder, 2000; Mao et al., 2001), parity (Domecq et al., 1997; Schroeder, 2000; Mao et al., 2001), milk yield (Schroeder, 2000; Pryce et al., 2001), initial level of reserves (Garnsworthy 
and Jones, 1987; Pedron et al., 1993; Ruegg and Milton, 1995) or feeding level (Friggens et al., 1998; Mao et al., 2001).

If this general pattern is consistent, it can be argued that a significant part of the mobilized reserves is not due to any of the factors mentioned above, but due to more basic species related genetic factors.

The biological basis and the supporting literature for this theory of cyclic nature of the body reserves in dairy cows have been clearly presented recently by Friggens (2001). In analysing this cyclic mobilization of body reserves, Friggens (2001) stated that body reserves in dairy cows are a safeguard for milk production at the beginning of the lactation, but its mobilization has negative consequences for the animal and the future offspring as lactation progresses. As a consequence of these concepts, targets of body fatness, which changes during the reproductive cycle, are assumed to exist in dairy cows.

In the FIRS, it is assumed that an optimal or reference level of body reserves or corporal condition (CC) curve exists for the whole lactation period of dairy cows. This optimal curve of CC should not only respect the needs of the animal for a high milk yield, but also be compatible with satisfactory achievements in reproductive performance and reduce to a minimum the risk of health problems. It is assumed that the difference between the $\mathrm{CC}$ value along that curve for two consecutive days, at any moment during the whole lactation period, is the optimal difference in terms of $\mathrm{CC}$ for that specific moment. If this daily optimal difference in $\mathrm{CC}$ units can be converted to energy units, the resulting value can be considered as the optimal daily energy balance for the dairy cow at that time of the lactation period.

A reference curve of body condition over the course of lactation has been published recently by Schroeder (2000). This reference curve has been formulated for high milk producing dairy cows (equal to or more than $9000 \mathrm{~kg} \mathrm{FCM} \mathrm{y}^{-1}$ ) combined with acceptable fertility traits (interval between partum less than 380 days) and minimal health disorders. This optimal or reference curve has been included in the FIRS and calculated with equation (46). The curve is shown in Figure 1.

Original values of the optimum body condition in dairy cows were determined as mm backfat. Backfat is designated as the thickness of the subcutaneous fat depot that develops under the skin of the animal and can be determined by different methods, e.g., by ultrasound measurements. As a measurement of body condition, backfat is not usually available at farm level or in experiments, but a more common way to express body condition is by measuring body condition score (BCS). BCS is a subjective method and is indicative of the animal's nutritional status and body energy reserves. This method combines palpation (touching/feeling) and visual observation of the thickness of soft tissues in the lumbar and pelvic region. There are different scoring scales to measure BCS, but the most common scoring system in use is that proposed by Edmonson et al. (1989) with a scale from 1 


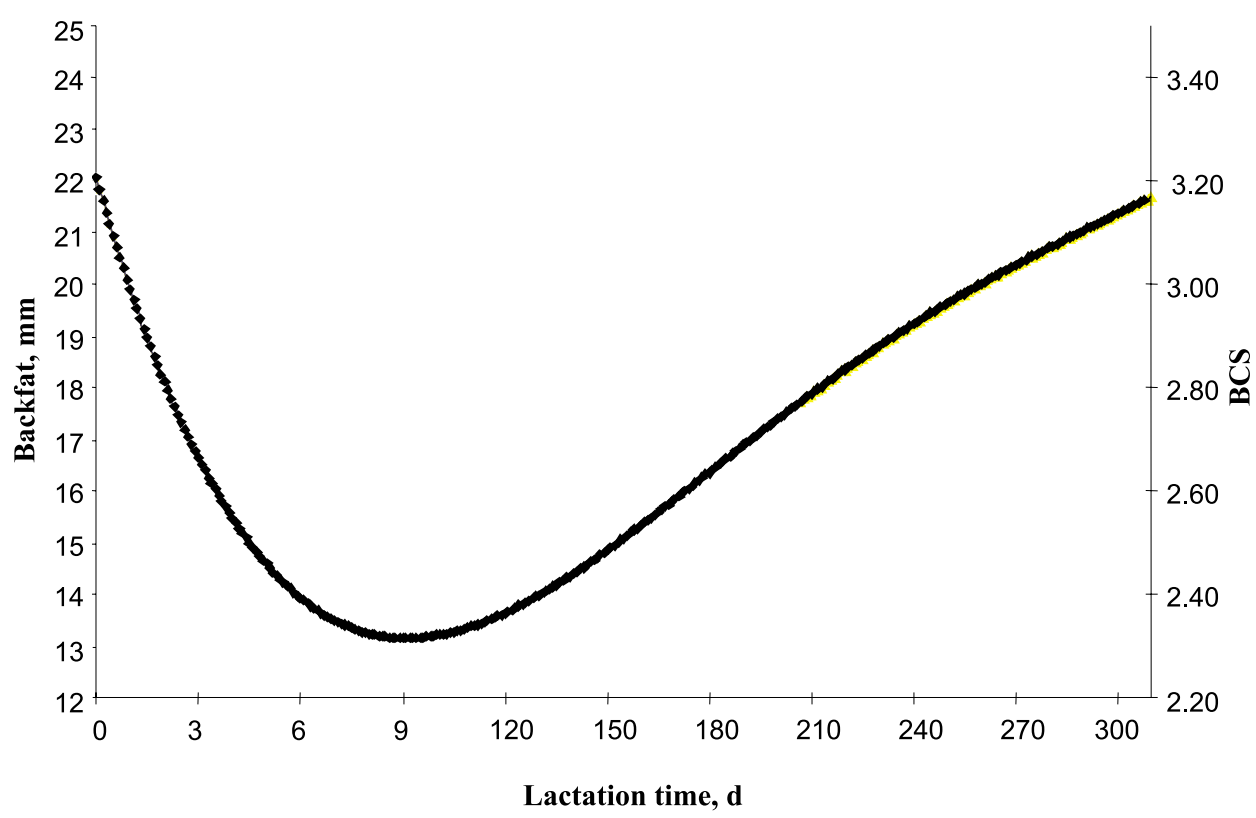

Figure 1. Reference curve of optimal corporal condition during the lactation period measured as backfat or as body condition score (Scale 1 to 5). Adapted from Schroeder, 2000

(emaciated cows) to 5 (very fat cows) with 0.5 point divisions. The BCS system has been considered as a valid measurement of subcutaneous fat (Domecq et al., 1995; Schwager-Suter et al., 2000; Friggens et al., 2001). The optimal backfat values as proposed by Schroeder (2000) are converted into units of the BCS scale (Edmonson et al., 1989) (45).

The optimum energy balance (E_bal_optimum) (42) in the model is a function of the optimum rate of change of body condition.

The optimum daily BCS change (BCSC_optimum) is determined as the difference between two BCS values estimated with a time distance of $24 \mathrm{~h} \mathrm{(43).} \mathrm{This}$ difference in terms of BCS units is converted to energy units by multiplying this value by the energy content per unit of BCS change. The energy equivalent to one unit of BCS change is variable depending on the amount of fat and protein being mobilized, and this in turn depends on the actual level of body reserves or body condition of the cow (Gibb et al., 1992). Various energy values can be found in the literature for gaining or losing of body tissue but little is published concerning the change of one unit of BCS. In the model, the energy value of one unit BCS change is calculated by the equation taken from Fox et al. (1999) for a cow with a shrunk body weight of $600 \mathrm{~kg}$ : 


$$
\text { BCSC }(\mathrm{MJ})=(950.74+368.7 \times \text { BCS_optimum }) \times \text { BCSC_optimum }
$$

In order to calculate the optimum BCS change, the model uses an internal function of Powersim named Delay that allows to keep the information of the variable, in this case the value of BCS_optimum, of the previous day. The name of the delayed variable in all cases along the FIRS model corresponds to the variable to be delayed and the prefix $D_{-}$, i.e. $D_{-} B C S \_$optimum is the delayed information of the variable BCS_optimum. Unless otherwise stated, the delay time of the delayed functions is $24 \mathrm{~h}$.

\section{Determination of BCS factor}

The last variable in the equation determining $E \_$diff_ $h$ is named Fac_BCS (47) and is included in order to account for the influence of initial (Adjust_Ini) and the actual (Adjust_Actual) BCS of the animal on feed intake. The theoretical basis for this factor has already been presented (see also Friggens, 2001). In the model this factor is modelled based on the condition of the cow at the start of the lactation, the optimal level of BCS during the lactation and the actual BCS of the animal as simulated by the model.

The effect of this factor would be divided in two according to the lactation time. At the beginning of the lactation this factor is mostly determined by Adjust_Ini (48) that depend on the initial BCS of the dairy cow (Initial_BCS) and this effect decreases as the lactation progresses, having almost no effect after the day 90 in lactation. The second term in equation (47) (Adjust_Actual) reflects the influence of the actual optimum BCS, as determined by the previously mentioned curve (BCS_optimum) and the actual value of BCS of the dairy cow as computed by the model (Upd_BCS). Adjust_Actual (49) at any point in lactation is estimated as the difference between the actual BCS of the animal (Upd_BCS) and the optimum BCS of the animal (BCS_optimum) at that time in lactation, times the energy content per unit of BCS $\left(E_{-} B C S \_h\right)$. $E_{-} B C S \_h$ is calculated in the same way as in equation 42, but using $U p d \_B C S$ instead of $B C S \_$optimum (50). Upd_BCS (51) is calculated once daily in the model at the beginning of each simulated day by the value of the variable during the preceding day $\left(D_{-} U p d \_B C S\right)$ plus the change in BCS during the day, (BCSC_M $(\mathbf{5 2})$ calculated by the model from the energy balance $\left(\mathrm{MJ} \mathrm{d}^{-1}\right)$. This equation (52) as in the case of equations (42) and (51) is estimated using the values of the energy content per unit of change of BCS as proposed by Fox et al. (1999). The variable (Sigm1) (53) makes sure that the effect of Adjust_Actual is not constant across the whole lactation period, but increases in a sigmoid fashion with a full effect at about 200 days in lactation.

Initial liveweight (Body_weight) is given as an input to the model and then is updated daily $\left(U p d \_B W\right)$ using the variable $E$ _balance and a net energy value of 
17.3 $\mathrm{MJ} \mathrm{kg}^{-1}$ liveweight loss and $20.9 \mathrm{MJ} \mathrm{kg}^{-1}$ liveweight gain. These values for liveweight loss and gain were reported by Gibb et al. (1992) for Holstein-Friesian cows. They were determined from a serial slaughter and carcass analysis in lactating dairy cows, which included different proportions of fat and protein mobilized or gained during the period of analysis. $U p d \_B W$ is used in the model for the determination of the comminution rate constant from large to small particles and of the liquid passage rate constant.

\section{The rumen digesta load}

The variable Rumen_load (55) represents the rumen digesta load in the model, which is the sum of all NDF fractions in the rumen. The NDF fraction of the rumen digesta has been used to represent the digesta load in other models of feed intake prediction (Williams et al., 1989; Fisher and Baumont, 1994; Fisher, 1996; Chilibroste et al., 1997; Tess and Kolstad, 2000).

\section{Feed intake regulation}

Once both elements of the Weston's theory, the energy deficit and the rumen digesta load, have been defined by the model, the next step is the integration of them into an equation describing the regulation of feed intake. In the FIRS this is represented by a group of equations (from 56 to 62 ).

An upper limit to accommodate digesta in the rumen has often been mentioned as the real factor deciding the end of a meal and consequently determining feed intake in dairy cows. A physical upper limit in rumen capacity exists and is determined by the total volume of the rumen, but as this space is always partially filled with digesta, a more precise word is rumen digesta load than rumen fill.

In most cases, this upper limit to accommodate digesta has been defined as a constant. Mertens (1987) proposed that until the cow covers its energy requirements, the rumen fill remains constant and only then decreases. Rejecting the concept of constant fill, Fisher et al. (1987) proposed a curvilinear relationship between rumen fill and energy balance. A logistic model describing maximum and minimum rumen fill modulated by palatability and energy balance was proposed by Faverdin et al. (1995). Variable upper and lower limits to rumen fill were also used by Danfaer (1998) and modelled according to the absorbed energy, body weight and the expected milk yield of the dairy cow.

Values for rumen digesta load or more specifically NDF rumen digesta load are available in the literature related to a different variables (i.e. feed intake, time from feeding, type of diet, energy intake, etc.). However, relationships between NDF rumen digesta load and energy deficit as proposed by Weston are scarce. But no values could be found in the literature relating energy difference as proposed 
in FIRS and NDF rumen digesta load. As a consequence the curve describing the upper limit of NDF rumen digesta used in the present model is totally theoretical, but based on sound values.

The upper limit of NDF digesta load in the rumen (Upper) (56) is determined in the FIRM model as a function of the energy difference $\left(E \_\right.$diff $\left.\_h\right)$ determined previously. This relationship is shown in Figure 2.

The constants Alfal to Alfa 5 determine the shape of the curve. The minimum value of the upper limit is set by the constant Alfal (4.15 kg NDF), while Alfa2 ( $4 \mathrm{~kg}$ ) is the difference between the minimum and the maximum value that $U p p e r$ can reach. Therefore, the maximum value of rumen digesta load in the model is $8.15 \mathrm{~kg}$ of NDF.

The lower limit of the digesta load in the model (Lower) (57) is given as a constant difference from the upper limit, in this case $0.6 \mathrm{~kg}$ of NDF. A constant difference between upper and lower limits was also used by Danfaer (1998) in his whole animal model.

Minimum and maximum values adopted for the mentioned limits are well within the range of values of NDF rumen content normally found in the literature. However, lower or higher values than the minimum (3.55 kg NDF) or maximum (8.15 kg NDF) values adopted in FIRS have been reported occasionally in the literature (Okine et al., 1991; Robinson et al., 1991; Lund, 2002).

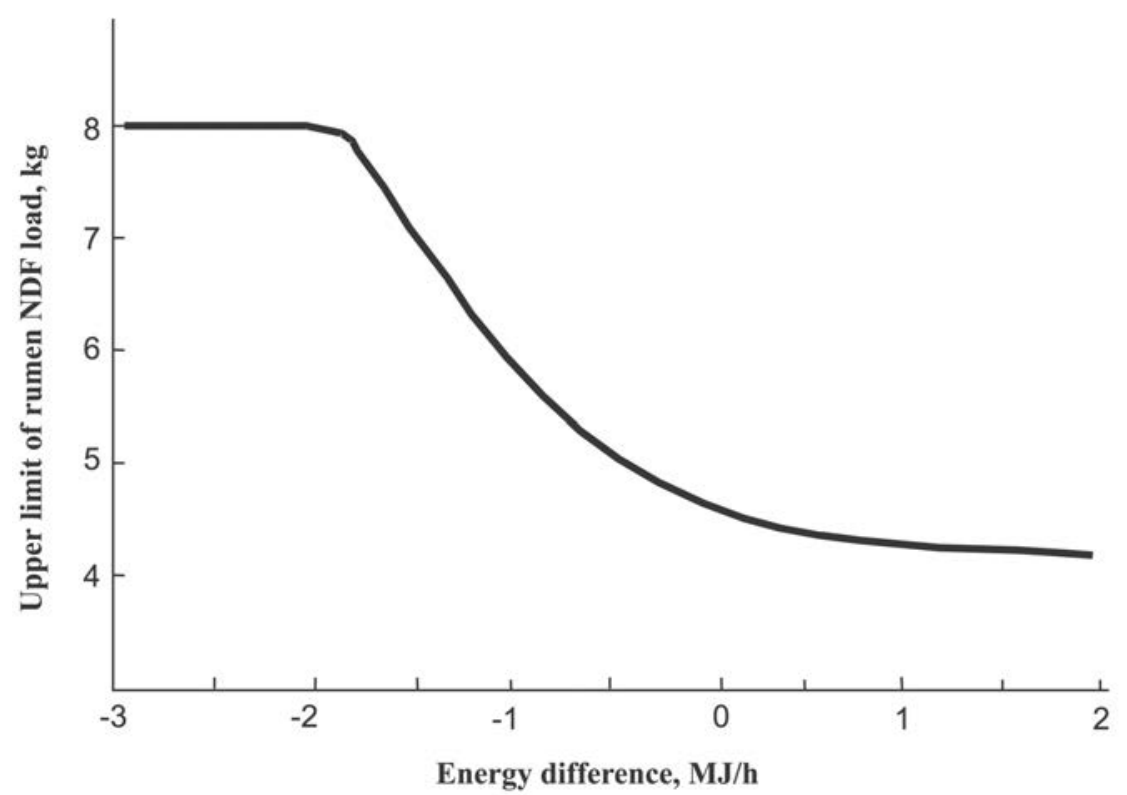

Figure 2. The relationship between energy difference as determined by the model and the upper limit of rumen NDF load 
When used as maximum rumen fill in the calculation of feed intake, different values were adopted. Mertens (1987) has estimated an NDF capacity of $6.6 \mathrm{~kg}$ for a cow with a body weight of $600 \mathrm{~kg}$ whereas a value of $5.5 \mathrm{~kg}$ of NDF was the value used by Madsen et al. (1994), close to the $5.4 \mathrm{~kg}$ used by Chilibroste et al. (1997) in his simulation model. With a few exceptions these values were fixed and are close to the middle point of the curve of NDF rumen load used by FIRS.

The decision between eating or not in the model is made through the equations 58 to 62, taken from Danfaer (1998). A schematic presentation of these equations is presented in Figure 3. In this graph, the cow stops eating when the rumen load (Line 1) is reaching the upper limit (NE Section) and is prevented from eating until the decreasing rumen digesta load reaches the lower limit. When this occurs,

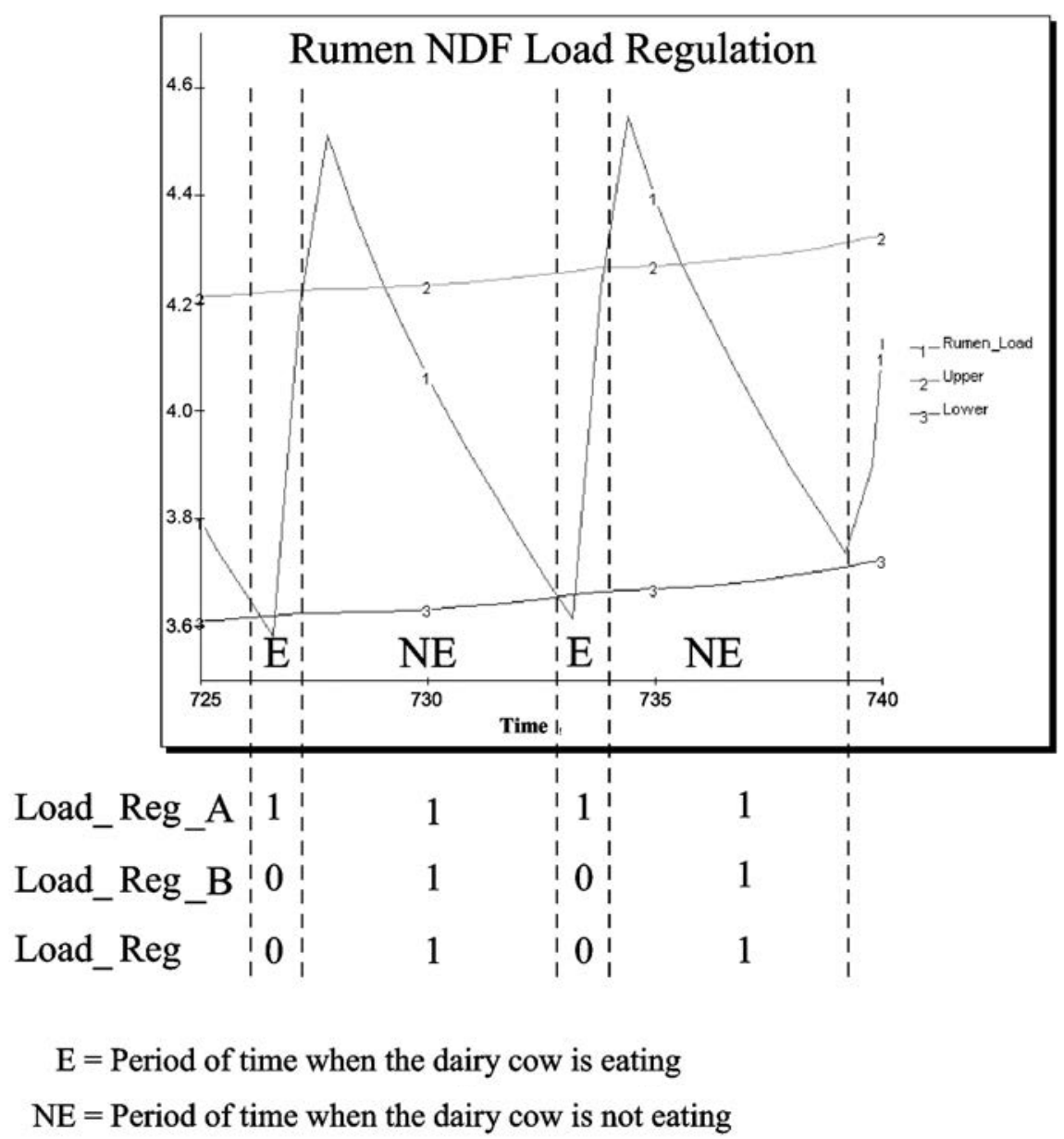

Figure 3. Rumen load regulation. Graphical representation of rumen digesta load and limits from a simulation in Powersim and results of the variables regulating feed intake in FIRS (see text) 
the eating starts (E Section) and continues until the upper limit is reached again. Lines 2 and 3 represent the upper and lower limit of digesta load, respectively. As shown in the graph, the upper limit and as a consequence the lower limit are not constant during the simulation period because the limits are dependent on $E$ diff $h$. The rate of eating (Eating) in the FIRS model is a constant with a value of $3.3 \mathrm{~kg} \mathrm{DM} \mathrm{h}^{-1}$. Danfaer (1998) in the Karoline model has made this rate variable and controlled by absorbed energy and expected milk yield.

\section{Preliminary behavioural evaluation}

A preliminary assessment of the behaviour of the model was carried out running FIRM with a typical diet as input. The diet was composed of grass silage and concentrates in the proportion of 65 and 35\%, respectively. The chemical composition of this diet used was (expressed as percentage of DM): NDF 42, crude protein 20 , starch 8 , sugars 3.5 and ash 10.5 . A dairy cow in its third parity weighing $600 \mathrm{~kg}$ with an initial body condition score of 3.2 and two different milk yields $\left(\right.$ Low $=7000$ or High $=9000 \mathrm{~kg} \mathrm{FCM} \mathrm{y}^{-1}$ ) was used as input for the model.

a) Feed intake
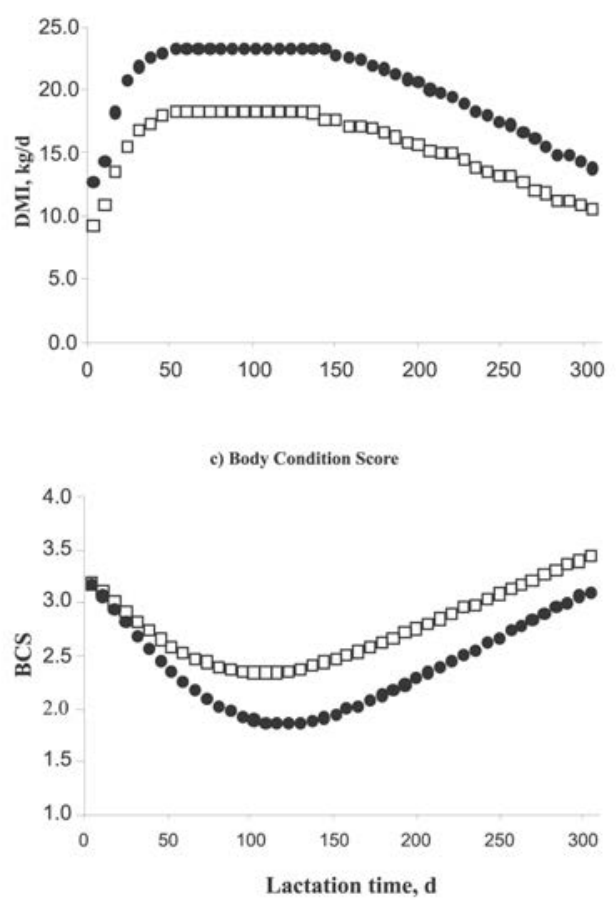

b) Milk yield

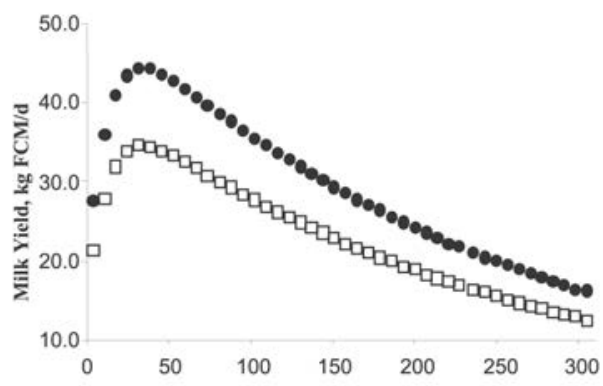

Figure 4. (a, b and c). Predicted values of dry matter intake, milk yield and body condition score during the lactation period for a cow producing $7000(\square)$ or $9000(\bullet) \mathrm{kg}_{\text {of FCM y}}{ }^{-1}$ 
Results produced by FIRM for the whole lactation period and for both milk yields are shown in Figure 4 ( $a, b$ and $c)$. Figure 4a shows dry matter intake predicted by the model for the Low and High milk yield. Typical curves are predicted with the highest intake for the cow producing more milk. Both milk production curves simulated by the model with peaks around day 35 in lactation are shown in Figure 4b. Curves of body condition score for Low and High milk production (Figure 4c) are consequences of the different intakes and milk yields shown in Figures $4 \mathrm{a}$ and $4 \mathrm{~b}$, respectively. Minimum BCS are obtained later in lactation for the cow with high milk yield than for the cow with low milk yield.

\section{CONCLUSIONS}

The aim of this work was to develop a dynamic, mechanistic and deterministic model of feed intake regulation in which the rumen function and the energy transactions representing the physical and metabolic regulation in the dairy cow are integrated. The traditional concept of intake regulation was rejected and the present model is based on a sound conceptual model of feed intake regulation, which has not previously been implemented in a working model.

The bi-phasic regulation theory states that either one or the other regulates the feed intake process whereas the present model regulates the feed intake process using both the physical and the metabolic signals as determinants of feed intake at every moment. Discrimination between physical or metabolic regulation, at least in the classical approach, is not possible with the present model.

Forage constraints acting mainly at the level of digesta flow are included in the model by the incorporation of a previously developed rumen model. Body reserves, both the absolute level and the rate of mobilization are integrated in the regulation of feed intake.

A preliminary evaluation of the model behaviour with a typical diet and for cows with different milk yield capacities has resulted in reasonable and expected simulated values for feed intake and body condition score. A further application and evaluation of the present model will be given in a forthcoming paper.

\section{AKNOWLEDGMENTS}

Horacio Petruzzi appreciates receiving a three years scholarship from the National Institute of Agricultural Technology, Argentina. 


\section{REFERENCES}

AFRC, 1993. Energy and Protein Requirements of Ruminants. CAB International, Wallingford (UK)

Chilibroste P., Aguilar C., Garcia F., 1997. Nutritional evaluation of diets. Simulation model of digestion and passage of nutrients through the rumen reticulum. Anim. Feed Sci. Tech. 68, 259-275

Coppock C.E., Flatt W.P., Moore L.A., Steward W.E., 1964. Effect of grain ratio on utilisation of metabolisable energy from milk production by dairy cows. J. Dairy Sci. 47, 1330-1338

Coulon J.B., Perochon L., Lescourret F., 1995. Modelling the effect of the stage of pregnancy on dairy cows' milk yield. Anim. Sci. 60, 401-408

Danfaer A., 1998. The Karoline Model. In: Proceeding from a Seminar held at the Swedish University of Agricultural Science, Karoline - Model for Feed Evaluation. Uppsala (Sweden), pp. 9-13

Domecq J.J., Skidmore A.L., Lloyd J.W., Kaneene J.B., 1995. Validation of body condition scores with ultrasound measurements of subcutaneous fat of dairy cows. J. Dairy Sci. 78, 2308-2313

Domecq J.J., Skidmore A.L., Lloyd J.W., Kaneene J.B., 1997. Relationship between body condition scores and milk yield in a large dairy herd of high yielding Holstein cows. J. Dairy Sci. 80, 101-112

Edmonson A.J., Lean I.J., Weaver L.D., Farver T., Webster G., 1989. A body condition scoring chart of Holstein dairy cows. J. Dairy Sci. 72, 68-78

Emmans G.C., Fisher C., 1986. Problems in nutritional theory. In: C. Fisher, K.N. Boorman (Editors). Nutrient Requirements of Poultry and Nutritional Research. Buttherworths, London (UK), pp. 9-39

Faverdin P., Baumont R., Ingvartsen K.L., 1995. Control and prediction of feed intake in ruminants. In: M. Journet, E. Grenet, C. Demarquilly, M.H. Farce, M. Theriez (Editors). Proceedings of the $\mathrm{IV}^{\text {th }}$ International Symposium on the Nutrition of Herbivores. INRA Recent Developments in the Nutrition of Herbivores. Paris, pp. 95-120

Fisher D.S., 1996. Modelling ruminant feed intake with protein, chemostatic and distension feedback. J. Anim. Sci. 74, 3076-3081

Fisher D.S., Baumont R., 1994. Modeling the rate and quantity of forage intake by ruminants during meals. Agr. Syst. 45, 43-53

Fisher D.S., Burns J.C., Pond K.R., 1987. Modeling ad libitum dry matter intake by ruminants as regulated by distension and chemostatic feedbacks. J. Theor. Biol. 126, 407

Fox D.G., Van Amburgh M.E., Tylutki T.P., 1999. Predicting requirements for growth, maturity, and body reserves in dairy cattle. J. Dairy Sci. 82, 1968-1977

Friggens N.C., 2003. Body lipid reserves and the reproductive cycle: towards a better understanding. Livest. Prod. Sci. 83, 219-236

Friggens N., Emmans G.C., Kyriazakis I., Oldham J.D., Lewis M., 1998. Feed intake relative to stage of lactation for dairy cows consuming total mixed diets with a high or low ratio of concentrate to forage. J. Dairy Sci. 81, 2228-2239

Friggens N., Emmans G.C., Veerkamp R.F., 1999. On the use of simple ratios between lactation curve coefficients to describe parity effects on milk production. Livest. Prod. Sci. 62, 1-13

Friggens N., Theilgaard P., Munch G., 2001. On the potential use of body condition score as a managment tool. In: Internal Report No. 148, Danish Institute of Agricultural Sciences, Research Centre Foulum (Denmark), pp. 31-41

Gallo L., Carnier P., Cassandro M., Mantovani R., Bailoni L., Contieron B., Bittante G., 1996. Change in body condition score of Holstein cows as affected by parity and mature equivalent milk yield. J. Dairy Sci. 79, 1009-1015

Garnsworthy P.C., Jones G.P., 1987. The influence of body condition at calving and dietary protein supply on voluntary food intake and performance in dairy cows. Anim. Prod. 44, 347-353 
Gibb M.J., Ivingst W.E., Dhanoa M.S., Sutton J.D., 1992. Changes in body components of autumncalving Holstein-Friesian cows over the first 29 weeks of lactation. Anim. Prod. 55, 339-360

Gordon F.J., Porter M.G., Maine S.C., Unsworth E.F., Kilpatrick D.J., 1995. Effect of digestibility and type of concentrate on nutrient utilisation by lactating dairy cattle. J. Dairy Res. 62, 15-27

Holter J.B., Slotnick M.J., Hayes H.H., Bozack C.K., Urban W.E., McGilliard M.L., 1990. Effect of prepartum dietary energy on condition score, postpartum energy, nitrogen partition, and lactation production responses. J. Dairy Sci. 73, 3502-3511

Lund P., 2002. The effect of forage type on passage kinetics and digestibility of fibre in dairy cows. Ph.D. Thesis. The Royal Veterinary and Agricultural University, Copenhagen (Denmark)

Madsen J., Stesing T., Weisbjerg M.R., Hvelplund T., 1994. Estimation of the physical fill of feedstuffs in the rumen by the in sacco degradation characteristics. Livest. Prod. Sci. 39, 43-47

Maltz E., Mizrach A., Flitsanov U., Spahr S., Murphy M.R., Novakofski J., 2001. Body weight and milk yield changes along lactation to evaluate and model body condition. In: Y. Van Der Honing (Editor). Book of Abstracts, Publication $\mathrm{N}^{\circ}$ 7, p.190

Mao I.L., Sloniewski K., Middelhede C.H., Madsen P., 2001. Body condition scores of lactating cows: Their use and genetic variation. In: Internal Report No. 148, Danish Institute of Agricultural Sciences, Research Centre Foulum (Denmark), pp. 43-60

Mertens D.R., 1987. Predicting intake and digestibility using mathematical models of ruminal function. J. Anim. Sci. 64, 1548-1558

Mertens D.R., 1994. Regulation of forage intake. In: G.C. Fahey (Editor). Forage Quality and Utilization. Madison, Wisconsin (USA), pp. 450-493

Mills J.A.N., Dijkstra J., Bannink A., Cammell S.B., Kebreab E., France J., 2001. A mechanistic model of whole-tract digestion and methanogenesis in the lactating dairy cow: Model development, evaluation and application. J. Anim. Sci. 79, 1584-1597

Okine E.K., Mathison G.W., 1991. Effects of feed intake on particle distribution, passage of digesta, and extent of digestion in the gastrointestinal tract of cattle. J. Anim. Sci. 69, 3435-3445

Pedron O., Cheli F., Senatore E., Baroli D., Rizzi R., 1993. Effect of body condition score at calving on performance, some blood parameters, and milk fatty acid composition in dairy cows. J. Dairy Sci. $76,2528-2535$

Perochon L., Coulon J.B., Lescourret F., 1996. Modelling lactation curves of dairy cows with emphasis on individual variability. Anim. Sci. 63, 189-200

Petruzzi H.J., Danfaer A., Norgaard P., 2002. A dynamic simulation model of nutrient digestion in the rumen of dairy cows. J. Anim. Feed Sci. 11, 367-397

Pittroff W., Kothmann M.M., 1999. Regulation of intake and diet selection by herbivores. Ecology of herbivores. In: Proceedings of the $\mathrm{V}^{\text {th }}$ International Symposium on the Nutrition of Herbivores, pp. 366-422

Pittroff W., Kothmann M.M., 2001. Quantitative prediction of feed intake in ruminants. III. Comparative example calculations and discussion. Livest. Prod. Sci. 71, 171-181

Pryce J.E., Coffey M.P., Simm G., 2001. The relationship between body condition score and reproductive performance. J. Dairy Sci. 84, 1508-1515

Rinne M., Huthanen P., Jaakkola S., 2002. Digestive processes of dairy cows fed silages harvested at four stages of grass maturity. J. Anim. Sci. 80, 1986-1998

Robinson P.H., McQueen R.E., 1991. Influence of rumen fermentable neutral detergent fiber levels on feed intake and milk production of dairy cows. J. Dairy Sci. 75, 520-532

Romo G.A., Casper D., Erdman R.A., Teter B.B., 1996. Abomasal infusion of Cis or Trans fatty acid isomers and energy metabolism of lactating dairy cows. J. Dairy Sci. 79, 2005-2015

Ruegg P.L., Milton R.L., 1995. Body condition scores of Holstein cows on Prince Edward Island, Canada: Relationship with yield, reproductive performance, and disease. J. Dairy Sci. 78, 552-564 
Sanders J.O., Cartwright T.C., 1979. A general cattle production systems model. I. Structure of the model. Agr. Syst. 4, 217-227

Schroeder U.J., 2000. An inquiry into the evaluation of body condition using ultrasonographic measurement of subcutaneous backfat thickness for the use in dairy herd management (in German). Ph.D. Dissertation. Freie Universität Berlin (Germany)

Schwager-Suter R., Stricker C., Erdin D., Kunzi N., 2000. Relationship between body condition scores and ultrasound measurements of subcutaneous fat and $m$. longissimus dorsi in dairy cows differing in size and type. Anim. Sci. 71, 465-470

Sutton J.D., Cammell S.B., Beever D.E., Humphries D.J., Phipps R.H., 1998. Energy and nitrogen balance of lactating dairy cows given mixtures of urea-treated whole-crop wheat and grass silage. Anim. Sci. 67, 203-212

Tess M.W., Kolstad B.W., 2000. Simulation of cow-calf production systems in a range environment: I. Model development. J. Anim. Sci. 78, 1159-1169

Waltner S.S., McNamara J.P., Hillers J.K., 1993. Relationship of body condition score to production variables in high producing Holstein dairy cattle. J. Dairy Sci. 76, 3410-3419

Weston R.H., 1985. The regulation of feed intake in herbage-feed ruminants. Proc. Nutr. Soc. Aust. $10,55-62$

Weston R.H., 1996. Some aspects of constraint to forage consumption by ruminants. Aust. J. Agr. Res. 47, 175-197

Wilkerson V.A., Glenn B.P., McLeod L.M., 1997. Energy and nitrogen balance in lactating cows fed diets containing dry or high moisture corn in either rolled or ground form. J. Dairy Sci. 80, 2487-2496

Williams C.B., Oltenacu P.A., Sniffen C.J., 1989. Applications of neutral detergent fibre in modelling feed intake, lactation response, and body weight changes in dairy cattle. J. Dairy Sci. 72, $652-663$

\section{STRESZCZENIE}

\section{Dynamiczny model regulacji pobrania paszy dla krów mlecznych. Opis modelu}

W pracy przedstawiono dynamiczny, mechanistyczny i deterministyczny model regulacji pobrania paszy przez krowy mleczne. Model ten bazuje na współzależności między funkcjonowaniem żwacza a przemianami energii, uwzględniającymi pobranie paszy. Model zawiera dwa wewnętrznie powiązane submodele: submodel żwacza (RS) bazujący na już istniejącym modelu żwacza i submodel regulacji pobrania pasz (F1RS). Na podstawie RS obliczone jest obciążenia żwacza (w kilogramach NDF). FIRS nie tylko opisuje regulacje pobierania paszy, lecz także trawienie, wchłanianie i wypływ składników pokarmowych ze żwacza. W tym modelu przemiany energii są związane z symulowaną różnicą między zdolnością wykorzystania energii a pobraniem energii metabolicznej. Wykorzystanie energii obejmuje nie tylko energię na potrzeby bytowe i na produkcję mleka u zwierzęcia, ale również energię potrzebną do zaspokojenia genetycznie uwarunkowanych rezerw organizmu. Rezerwy organizmu, zarówno wartość względna, jak i tempo odkładania, uwzględniane są w modelu regulacji pobrania paszy. Wstępna ocena modelu dla typowej dawki i pobrania wykazała, że prognozowane wartości są mniejsze od oczekiwanych w zakresie pobrania paszy, kondycji i masy ciała. 


\section{APPENDIX}

E_diff_h $=$ E_balance - E_bal_optimum + Fac_BCS, $M J h^{-1}$

E_balance $=$ ME - HE- Daily_Preg_E_Ret $/ 24-$ Milk_E/24, $M J h^{-1}$

$\mathrm{ME}=\mathrm{GE}$ intake - Faecal_E - Methane_E - Urinary_E, $M J h^{-1}$

$\mathrm{GE}$ intake $=\mathrm{DMI} \times \mathrm{GE}, \bar{M} J h^{-1}$

Faecal_E $=$ Faecal_C $\times 0.546+$ Faecal_N $\times 23.7 / 11.423, M J h^{-1}$

Faecal_C $=$ NDF_SI + OtherCHO_SI + Sugar_starch_HG

+ Lipid_HG + Protein_HG $\times 3.8-\left(\mathrm{Ab} \_\mathrm{AC} \_-\overline{\mathrm{HG}}+\mathrm{Ab}-\mathrm{PR} \_\mathrm{HG}\right.$

$\left.+\mathrm{Ab} \_\mathrm{BU} \_\mathrm{HG}+\mathrm{CH} 4 \_\mathrm{HG}+\mathrm{CO} 2 \_\mathrm{HG}\right), \mathrm{mol}^{\mathrm{C}} h^{-1}$

NDF_SI $=$ NDF_Passage $\times \mathrm{CCCHO} / 24, \mathrm{~mol} \mathrm{Ch}^{-1}$

OtherCHO_SI $=$ P_OCL + P_OCS + O_MIC $\times 0.0937, \mathrm{~mol} \mathrm{Ch}^{-1}$

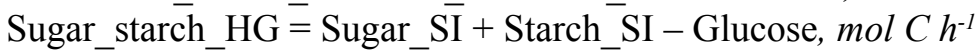

Sugar_SI $=$ P_SU + O_MIC $\times 0.1817 \times 3 / 51, \mathrm{~mol} \mathrm{Ch}^{-1}$

Starch_SI $=\overline{\text { ST_passage }} \times \mathrm{CCCHO} / 24+\mathrm{O} \_\mathrm{MIC} \times 0.1351, \mathrm{~mol}^{\mathrm{C}} h^{-1}$

Glucose $=($ Sugar_SI + Starch_SI $) \times 0.884, \mathrm{~mol} \mathrm{C}^{-1}$

Lipid_HG $=$ Lipid_SI - Fatty_acids, $m o l C^{-1}$

Lipid_SI $=$ P_LI + O_MIC $\times 0.1817 \times 48 / 51, \mathrm{~mol} \mathrm{Ch}^{-1}$

Fatty_acids $=$ Lipid_SI $\times 0.833, \mathrm{~mol} \mathrm{Ch}^{-1}$

Protein_HG $=$ Protein_SI + Endog_protein - Amino_acids, $m o l ~ N h^{-1}$

Protein_SI $=\mathrm{P}_{-} \mathrm{A} 33+\mathrm{P}_{-} \mathrm{A} 2 \mathrm{~L}+\mathrm{P}_{-} \mathrm{A} 2 \mathrm{~S}+\mathrm{P}_{-} \mathrm{A} 1 \mathrm{~L}+\mathrm{P}_{-} \mathrm{A} 1 \mathrm{~S}+\mathrm{O} \_\mathrm{MIN}$, $\operatorname{mol~N} \bar{h}^{-1}$

Endog_protein $=\mathrm{DMI} \times \mathrm{K} \_\mathrm{EP}$, mol $N h^{-1}$

Amino_acids $=$ Protein_SI $\times 0.735, \mathrm{~mol} \mathrm{~N}^{-1}$

Fermentable_HG $=$ NDF_SI + OtherCHO_SI + Sugar_starch_HG +

(Protein_HG-Endog_protein) $\times 3.8, \mathrm{~mol} C h^{-1}$

$\mathrm{Ab} \_$AC_HG $=$Fermentable_HG $\times 0.0813, \mathrm{~mol} \mathrm{Ch}^{-1}$

$\mathrm{Ab}$ PR_HG $=$ Fermentable_HG $\times 0.0355, \mathrm{~mol} \mathrm{Ch}^{-1}$

$\mathrm{Ab} \_\mathrm{BU} \_\mathrm{HG}=$ Fermentable_HG $\times 0.0242, \mathrm{~mol} \mathrm{C}^{-1}$

$\mathrm{CH} 4 \_\mathrm{HG}=$ Fermentable_HG $\times 0.0158, \mathrm{~mol} \mathrm{Ch} h^{-1}$

$\mathrm{CO} 2 \_\mathrm{HG}=$ Fermentable_HG $\times 0.0382, \mathrm{~mol} \mathrm{C}^{-1}$

Faecal_N $=$ Protein_HG $-0.184, \mathrm{~mol} \mathrm{~N} h^{-1}$

Methane_E $=\left(\mathrm{Ab} \_\overline{\mathrm{C}} \mathrm{H} 4+\mathrm{CH} 4 \_\mathrm{HG}\right) \times 0.75 \times 0.890, M^{-1} h^{-1}$

Urinary_E $=\mathrm{K} \_\mathrm{UE} \times \mathrm{GE}$ intake, $M J h^{-1}$

$\mathrm{HE}=\mathrm{HE} \_$Preg $/ 24+\mathrm{GE}$ intake $\left.\times\left(37.813-\mathrm{K} \_\mathrm{HE} * \mathrm{MY}\right) / 100\right), M J h^{-1}$

HE_Preg $=$ Daily_Preg_E_Ret $\times(1 / 0.133-1), M J d^{-1}$

$\mathrm{MY}=\left\{\mathrm{a} \_1 \times\left[\mathrm{EXP}\left(-\mathrm{EXP}\left(\mathrm{Go}-\mathrm{b} \_1 \times\right.\right.\right.\right.$ Lactation_time $\left.\left.)\right)\right]$

$\times\left[\operatorname{EXP}\left(-\mathrm{c} \_1 \times\right.\right.$ Lactation_time $\left.)\right]+$ MY_Preg_Red $\}, l d^{-1}$

Lactation_time $=$ IF $($ TIME $<=$ Day1, Ini_Lact time, INT (TIME - Day1) $/$

Day1 $)+$ Ini_Lact_time $+1-\operatorname{TIMECYCLE}(0, \bar{D}$ ay1 $)), d$

MY_Preg_Red $=\left(-\mathrm{e}^{-\mathrm{aMR}} \times\left[(\mathrm{PW}-18) \times \mathrm{e}^{-\mathrm{bMR} * \mathrm{PW}}\right]\right), l d^{-1}$ 
$\mathrm{PW}=($ Lactation_time - Conception_day $) / 7$, week

Daily_Preg_E_Ret $=0.025 \times$ Calf_Birth_W $\times$

(Total_Preg_E_Ret $\times 0.0201 \times \mathrm{EXP}(-0.0000576 \times \mathrm{PW} \times 7) M J d^{-1}$

Total_Preg_E_Ret $=10^{\wedge}(151.665-(151.64 \times$ EXP $(-0.0000576$

$\times \mathrm{P}(\overline{\mathrm{W}} \times 7)), M \bar{J}$

Milk_E $=$ MY $\times$ EV_Milk, $M J d^{-1}$

EV_Milk $=0.0384 \times$ Butterfat_Milk $+0.0223 \times$ Protein_Milk $+0.0199 \times$

Lactose Milk-0.108, $\mathrm{MJ}^{-1}$

EV_Milk $=0.0376 \times$ Butterfat_Milk $+0.0209 \times$ Protein_Milk+0.948, MJ $l^{-1}$

EV_Milk $=0.0406 \times$ Butterfat_Milk $+1.509, M J^{-1}$

EV_Milk $=3.14, M J l^{-1}$

E_bal_optimum $=($ BCSC_optimum $\times($ BCS_optimum

$\times \overline{3} 68.7+950.74)) / 24, \overline{M J} h^{-1}$

BCSC_optimum $=$ BCS_optimum - D_BCS_optimum

D_BCS_optimum $=$ DELAYPPL $\left(\right.$ BCS $\bar{S} \_$optimum, 24,0$)$

BCS_optimum $=$ RBF_Optimum $\times 0.1+1$

RBF_Optimum $=$ Lact1-Lact $2 \times$ Lactation_time + Lact3

$\times$ Lactation_time ${ }^{\wedge} 2$-Lact $4 \times$ Lactation_time ${ }^{\wedge} 3+$ Lact5

$\times$ Lactation_time $^{\wedge} 4, \mathrm{~mm}$

Fac_BCS $=$ - Adjust_ini + Adjust_Actual, $M J h^{-1}$

Adjust_ini $=(2.125-0.625 \times$ Initial_BCS $) \times \operatorname{EXP}\left(-C t e \_137 \times(\right.$ TIME $)$,

$M J h^{-1}$

Adjust_Actual $=($ E_BCS_h $\times($ Upd_BCS - BCS_optimum $))$

/ K_BC $\overline{C S} \times \operatorname{Sigm} 1, \bar{M} J h^{-1}$

E_BCS_h $=($ Upd_BCS $\times 368.7+950.74) / 24, M J h^{-1}$

Upd_BCS $=$ D_Upd_BCS + BCSC_M

BCSC_M $=($ E_balance $/(950.74+368.7 \times$ D_Upd_BCS $)$

Sigm $1=1$-EXP $\left(-\right.$ cte $1 \times$ Lactation_time ${ }^{\wedge}$ Cte 3$)$

Rumen_load $=$ TPR / 37.037, $\mathrm{kg}$

$\mathrm{TPR}=\overline{\mathrm{C}} 1 \mathrm{~L}+\mathrm{C} 1 \mathrm{~S}+\mathrm{C} 2 \mathrm{~L}+\mathrm{C} 2 \mathrm{~S}$, mol C

Upper $=$ alfa $1+$ alfa2 $\times \operatorname{EXP}\left(-\right.$ alfa3 $\times(\text { E_diff_h+alfa5 })^{\wedge}$ alfa4 $), k g$

Lower $=$ Upper - Diff, $k g$

Load_RegA $=$ IF $($ Der_Load $<0$ AND Rumen_load $<$ Lower, 0,1$)$

Load_RegB $=$ IF (Der_Load $>=0$ AND Rumen_load $<$ Upper, 0,1$)$

Load_Reg $=$ Load_RegA $\times$ Load_RegB

$\mathrm{DMI}=\mathrm{IF}($ Load_Reg $=0$, Eating, 0$), \mathrm{kg} D M h^{-1}$

Feed_intake $=24 \times$ INTEGRATE (DMI) $/$ TIME, $k g D M d^{-1}$ 